\title{
Studi Manajemen Energi Di Rumah Sakit Prima Medika Denpasar
}

\author{
Cecep Yudhie Rachmat ${ }^{1}$, Satya Kumara ${ }^{2}$, Dayu Giriantari ${ }^{3}$ \\ [Submission: 28-09-2018, Accepted: 31-03-2019]
}

\begin{abstract}
Prima Medika Hospital is a nationally accredited hospital with the highest category or Plenary in 2016. With the highest patient visit rate of 59,289 people in 2017 and an average occupancy rate of $79.89 \%$ is entered into the ideal category with electricity consumption of 2,299,077 $\mathrm{kWh} /$ year. Electricity expenses come from 5 equipment groups, namely: lighting equipment group $20.08 \%$, equipment for air arrangement system $56.12 \%$, medical equipment $8.92 \%$, office equipment $5.30 \%$ and utilities utilities $9.57 \%$. From the initial energy audit calculation, the Energy Consumption Intensity index is $344.23 \mathrm{kWh} / \mathrm{m}^{2} /$ year and this is included in the Intensive Energy category or shows wasteful energy use. Energy conservation efforts will be carried out on all equipment groups, especially to the equipment of the air structuring system which is the biggest energy absorber starting from the assumption of equipment operating hour patterns and then searching for energy-saving potentials starting from the lighting equipment group in the form of lamp replacement with Light type Emitting Diode (LED), from the office equipment group with the control of operating hours of Dispenser equipment and from the group of air structuring equipment with the replacement of standard AC technology into AC inverters, the total potential of electricity energy savings was $613,813.2 \mathrm{kwh} /$ year or $26.70 \%$ so if the proposed Energy Saving Opportunity can be implemented then the final value can be reduced to $252.33 \mathrm{kWh} / \mathrm{m}^{2} /$ Year or included in the Energy Standard category or already efficient.
\end{abstract}

Intisari- Rumah Sakit Prima Medika adalah rumah sakit yang telah terakreditasi tingkat nasional dengan katagori tertinggi atau Paripurna di 2016. Dengan tingkat kunjungan pasien tertinggi sebanyak 59.289 orang ditahun 2017 dan tingkat hunian rata rata $79,89 \%$ masuk katagori ideal dengan konsumsi energi listrik sebesar 2.299.077 $\mathrm{kWh} /$ tahun. Beban kelistrikan berasal dari 5 kelompok peralatan yaitu: kelompok peralatan penerangan $20,08 \%$, peralatan sistem penataan udara $56,12 \%$, peralatan medis $8,92 \%$, peralatan kantor $5,30 \%$ dan peralatan utiliti 9,57\%. Dari perhitungan audit energi awal diperoleh indeks Intensitas Konsumsi Energi (IKE) sebesar 344,23 $\mathbf{k W h} / \mathrm{m}^{2} /$ tahun dan ini termasuk dalam katagori Energi Intensive atau menunjukan penggunaan energi yang boros. Akan dilakukan upaya konservasi energi pada semua kelompok peralatan terutama kepada peralatan sistem penataan udara yang merupakan penyerap energi terbesar dimulai dari menyusun asumsi pola jam oprasional peralatan selanjutnya dilakukan upaya pencarian terhadap potensi-potensi hemat energi mulai dari kelompok peralatan penerangan berupa penggantian lampu dengan yang berjenis Light Emitting Diode (LED), dari kelompok peralatan kantor dengan penertiban jam oprasional alat Dispenser dan dari kelompok peralatan penataan udara dengan

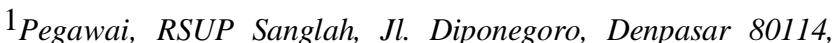
INDONESIA (telp: 0361-227911; fax: 0361-224206; e-mail: cecep.yudhie@gmail.com)

2, 3 Dosen, Jurusan Teknik Elektro, Fakultas Teknik Universitas Udayana, Jln. Jalan Kampus Bukit Jimbaran 80361 INDONESIA (telp:0361-703315; fax:0361-4321; e-mail: penulis2@unud..ac.id) penggantian teknologi AC standart menjadi AC inverter didapatkan total potensi penghematan energi listrik sebesar $613.813,2 \mathrm{kwh} /$ tahun atau sebesar $26,70 \%$ sehingga jika usulan Peluang Hemat Energi (PHE) ini dapat diimplementasikan maka nilai IKE akhir dapat menurun menjadi $252,33 \mathrm{kWh} / \mathrm{m}^{2} /$ Tahun atau masuk dalam katagori Energy Standart atau sudah efisien

Kata Kunci - Manajemen Energi, Intensitas Konsumsi Energi, Peluang Hemat Energi, Efisiensi, Rumah Sakit, Light Emitting Diode (LED)

\section{PENDAHULUAN}

Pemerintah melalui Instruksi Presiden (INPRES) nomor 10 tahun 2005 tentang penghematan energi telah menetapkan program konservasi energi agar diterapkan pada setiap konsumen pengguna energi seperti tertuang dalam di instansi perkantoran, badan usaha milik negara atau badan usaha milik daerah [14] Rumah Sakit sebagai salah satu institusi pelayanan publik dibidang kesehatan yang juga sebagai konsumen pengguna energi diharapkan dapat turut serta dalam mensukseskan kebijakan terkait penghematan pemakaian listrik tanpa harus mengurangi aktifitas, kualitas serta kenyamanan bagi pasien. Rumah Sakit (RS) Prima Medika, Denpasar adalah satu instansi swasta pengguna energi kelistrikan yang telah terakreditasi Paripurna oleh Komite Akreditasi Rumah Sakit (KARS) di tahun 2016, memiliki luas area $2920 \mathrm{~m}^{2}$, beroprasional selama 24 jam setiap hari dengan persentase tingkat hunian atau Bed occupancy Ratio (BOR) tertinggi 99,92\% dan tingkat kunjungan tertingginya 61.684 orang [6]. Jumlah tagihan listrik tahun 2016 sebesar Rp 2.414.153.700,- [7] dan tahun 2017 sebesar Rp. 2.273.336.834,- [8] Jumlah tagihan listrik tersebut tersebut berasal dari penggunaan energi listrik kelompok oleh peralatan sistem penerangan, peralatan sistem pengkondisian udara, peralatan medis, peralatan perkantoran dan peralatan utiliti. Besarnya tagihan kelistrikan yang harus dibayarkan menyebabkan rumah sakit berupaya mencari peluang-peluang penghematan energi tersebut. Langkah awal yang dilakukan dalam penelitian ini adalah dengan melakukan observasi awal serta pengumpulan data data pendukung termasuk Selanjutnya dilakukan audit energi awal dengan menghitung besarnya Intensitas Konsumsi Energi (IKE), dengan menggunakan rumus [4]:

$\mathrm{IKE}=\frac{k \text { Wh total setahun }}{(\text { tingkat hunian } \times \text { area room })+(\text { area non room })}$

Penilaian kreteria Pengelolaan Energi dengan menggunakan nilai standart Asean Data Base Officers 1990, untuk penetapan kreterianya [4]:

1. Energy Efficient menunjukan pemakaian energi yang p-ISSN:1693 - 2951; e-ISSN: 2503-2372

Cecep Yudhie Rachmat: Studi Manajemen Energi di Rumah ... 
sangat efisien pada suatu bangunan/gedung.

2. Energy Standart menunjukan energi terkelola dengan baik dan sudah menerapkan hemat energi atau efisien

3. Base Case menunjukan energi tidak terkelola dengan baik namun tidak termasuk kategori boros atau cukup efisien

4. Energy Intensive menunjukan pemakaian energi yang boros

TABEL I

NILAI INDEKS KONSUMSI ENERGI (IKE)

\begin{tabular}{|c|c|c|c|}
\hline No & $\begin{array}{c}\text { Nilai Indeks } \\
\text { Konsumsi } \\
\text { Energi (IKE) }\end{array}$ & \multicolumn{2}{|c|}{ Katagori } \\
\hline 1 & $180 \mathrm{kWh} / \mathrm{m}^{2} /$ tahun & $\begin{array}{c}\text { Energy } \\
\text { Efficient }\end{array}$ & $\begin{array}{c}\text { Sangat } \\
\text { Efisien }\end{array}$ \\
\hline 2 & $\begin{array}{c}270>\mathrm{IKE}>180 \\
\mathrm{kWh} / \mathrm{m}^{2} / \mathrm{tahun}\end{array}$ & $\begin{array}{c}\text { Energy } \\
\text { Standart }\end{array}$ & Efisien \\
\hline 3 & $\begin{array}{c}340>\mathrm{IKE}>270 \\
\mathrm{kWh} / \mathrm{m}^{2} / \mathrm{tahun}\end{array}$ & $\begin{array}{c}\text { Base Case } \\
\text { Cukup } \\
\text { Efisien }\end{array}$ \\
\hline 4 & $\begin{array}{c}\mathrm{IKE}>340 \\
\mathrm{kWh} / \mathrm{m}^{2} / \text { tahun }\end{array}$ & $\begin{array}{c}\text { Energi } \\
\text { Intensive }\end{array}$ & Boros \\
\hline
\end{tabular}

\section{METODE PENELITIAN}

\section{1) Sumber Data}

Sumber data berupa Data primer yang diperoleh dari pengukuran beban-beban yang dioperasikan, studi literatur yang berkaitan dengan tema pembahasan, data sekunder yang diperoleh secara tidak langsung dan bersumber dari profil Organisasi, single line diagram sistem kelistrikan, rekening pembayaran listrik pada tahun 2016 dan 2017, denah dari bangunan gedung, data inventaris peralatan tahun 2017.

\section{2) Jenis data}

Jenis data pada penelitian ini adalah Data kuantitatif yaitu data yang berbentuk angka-angka atau data yang dapat dihitung meliputi data tagihan listrik, data jumlah lampu, jumlah mesin, jumlah alat-alat bertenaga listrik, kapasitas daya dan lama penggunaan perharinya. Data kualitatif yaitu data dalam bentuk kata-kata (kalimat) seperti penjelasan gambar, objek penelitian.

\section{3) Metode Pengumpulan Data}

dengan cara metode Interview, yaitu dengan melakukan wawancara dengan pihak-pihak (responder) yang terkait. Observasi, yaitu dengan mengadakan pengamatan, pencatatan dan pengukuran seperti pencatatan spesifikasi alat, pengukuran nilai tegangan pada objek penelitian. Studi literatur, yaitu dengan pengumpulan data dari buku-buku, jurnal, tesis dan hasil penelitian yang terkait manajemen energi. Dokumentasi yaitu dengan mendata dari arsip atau dokumen milik rumah sakit atau dokumentasi pribadi dan melakukan analisis terhadap hasil yang diperoleh

\section{A. Alur Penelitian}

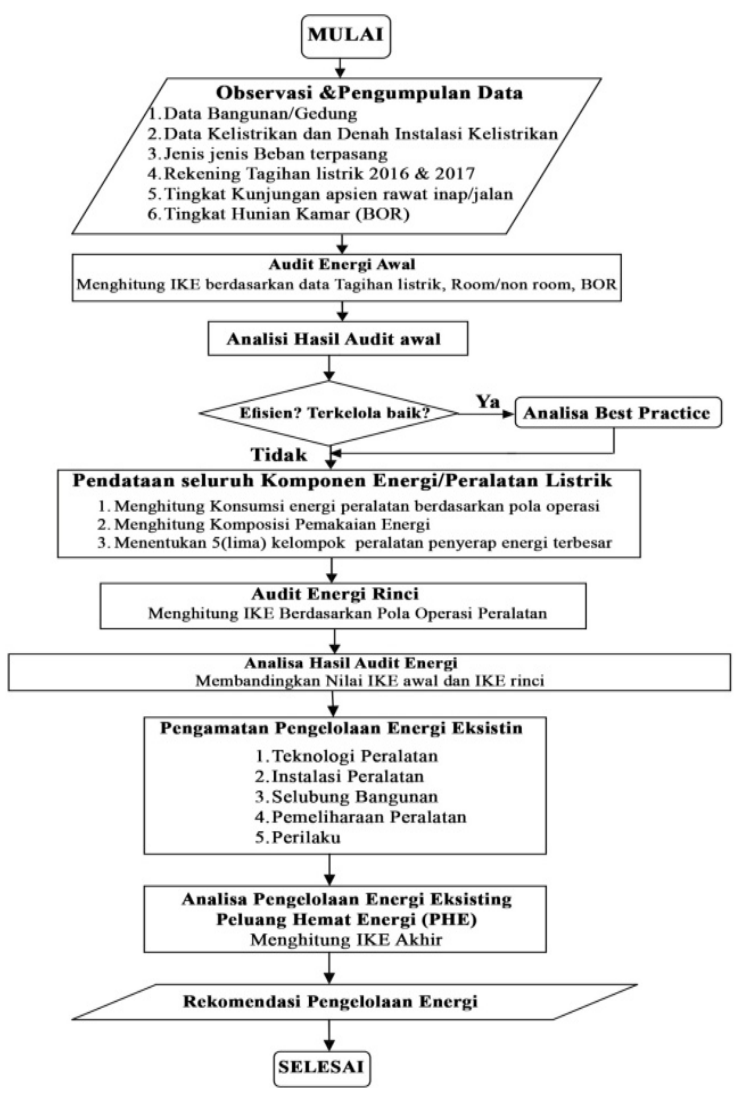

\section{PEMBAHASAN}

\section{A. Data Kunjungan Pasien}

Dari data kunjungan pasien tahun 2012 sampai 2017 didapat kunjungan pasien rawat jalan tertinggi terjadi pada tahun 2014 sebanyak 61.684 orang/tahun dan kunjungan pasien rawat jalan terendah tahun 2002 sebanyak 1569 orang/tahun dengan rerata kunjungan pasien sebanyak 42.956 orang/tahun atau 3.579 orang/bulan.

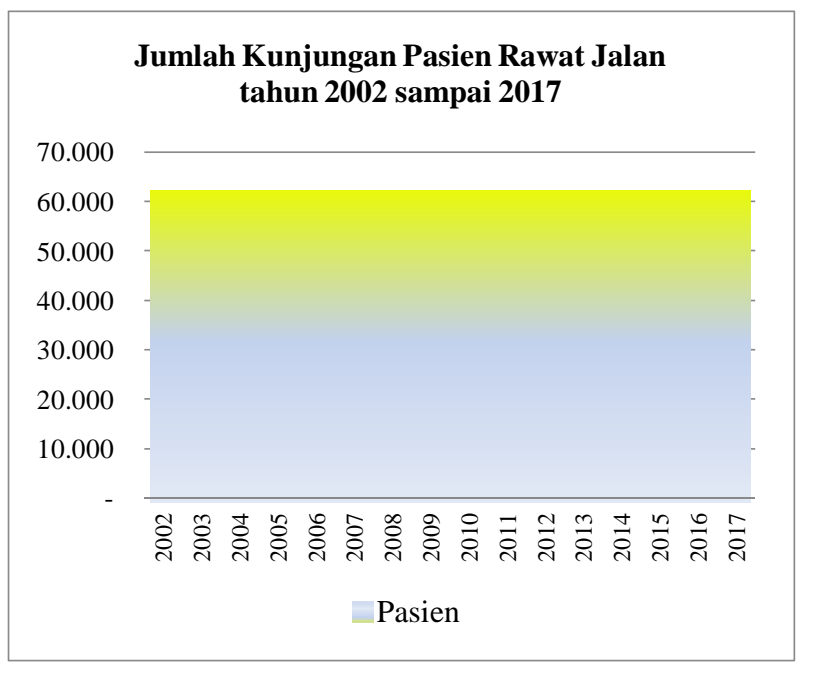

Gambar 1: Jumlah kunjungan pasien rawat jalan tahun 2002 sampai 2017 2017

Data kunjungan pasien yang lebih detail dilihat pada data tahun 
TABEL III

KUNJUNGAN PASIEN RAWAT JALAN DAN INAP TAHUN 2017

\begin{tabular}{|l|c|c|c|}
\hline \multirow{2}{*}{ Bulan } & \multicolumn{2}{|c|}{ Jumlah pasien } & \multirow{2}{*}{ Total } \\
\cline { 2 - 3 } & $\begin{array}{c}\text { Rawat } \\
\text { Jalan }\end{array}$ & $\begin{array}{c}\text { Rawat } \\
\text { Inap }\end{array}$ & \\
\hline Januari & 4484 & 359 & 4843 \\
\hline Februari & 4393 & 973 & 5366 \\
\hline Maret & 3751 & 846 & 4597 \\
\hline April & 4331 & 1010 & 5341 \\
\hline Mei & 4286 & 918 & 5204 \\
\hline Juni & 4321 & 959 & 5280 \\
\hline Juli & 3934 & 872 & 4806 \\
\hline Agustus & 3710 & 773 & 4483 \\
\hline September & 3608 & 720 & 4328 \\
\hline Oktober & 3914 & 778 & 4692 \\
\hline November & 4341 & 864 & 5205 \\
\hline Desember & 4260 & 884 & 5144 \\
\hline Jumlah & $\mathbf{4 9 . 3 3 3}$ & $\mathbf{9 . 9 5 6}$ & $\mathbf{5 9 . 2 8 9}$ \\
\hline
\end{tabular}

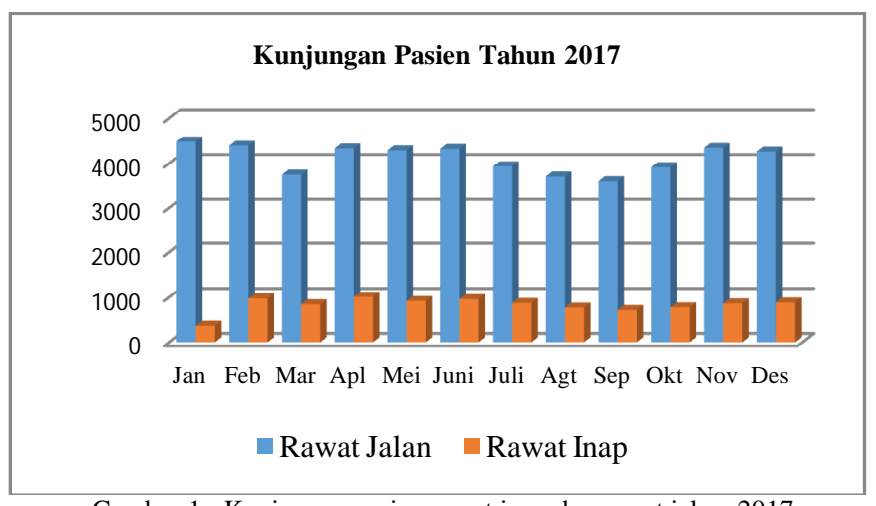

Gambar 1: Kunjungan pasien rawat inap dan rawat jalan 2017

\section{B. Tingkat Hunian Kamar}

Jumlah tingkat hunian kamar rumah sakit atau BOR (Bed Occupation Rate) tertinggi sebesar 99,92\% yang diraih pada tahun 2010 dan BOR yang terendah pada tahun 2002 yaitu sebesar $45,47 \%$.

\section{BOR Periode 2002-2016}

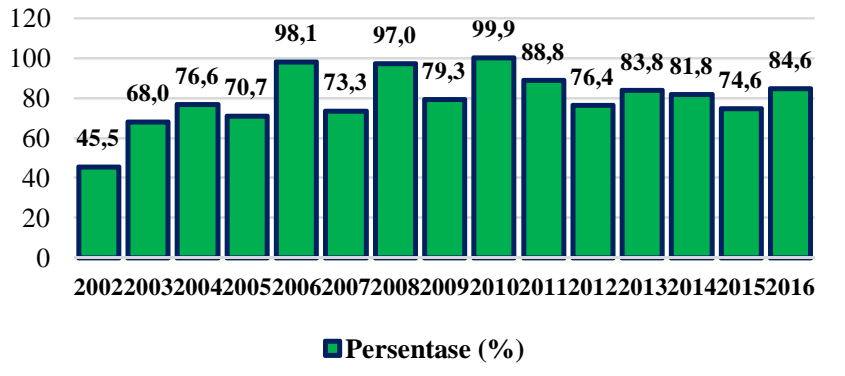

Gambar 3: Bed Occupation Rate (BOR) RS Prima Medika 2001-2016
Departemen Kesehatan, 2015 rerata BOR sebesar 79,89\% termasuk dalam katagori ideal.

\section{Belanja Energi Kelistrikan}

Tagihan bulanan pemakaian listrik tahun 2016 dan 2017 adalah sebesar.

TABEL IIIII

BELANJA ENERGI LISTRIK TAHUN 2016 DAN 2017

\begin{tabular}{|l|c|c|}
\hline \multirow{2}{*}{ Bulan } & \multicolumn{2}{|c|}{ Tagihan Listrik ( Dalam Jutaan } \\
Rupiah)
\end{tabular}

Besarnya belanja listrik RS Prima Medika untuk tahun 2016 adalah Rp 2.414.000.000,- dan untuk tahun 2017 besarnya adalah $\mathrm{Rp}$ 2.273.000.000,-

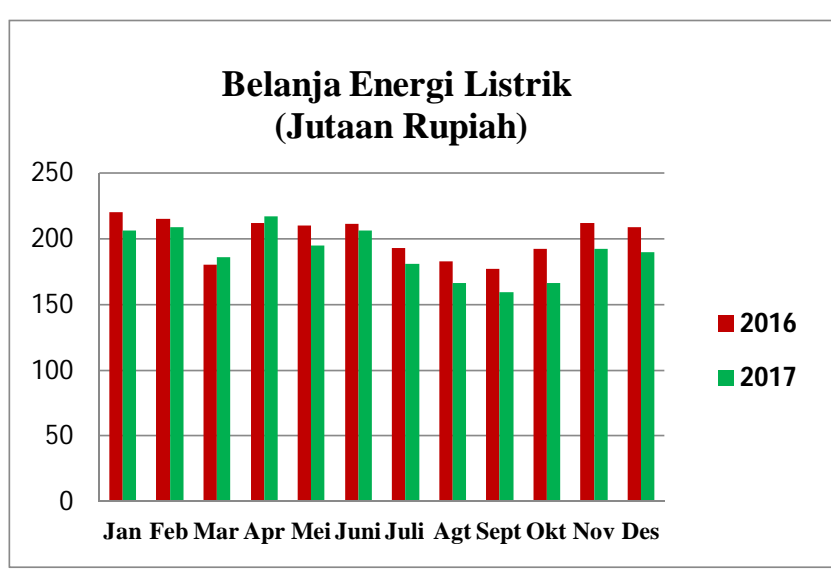

Gambar 4: Grafik belanja energi listrik tahun 2016 dan 2017

D. Komposisi Bangunan RS Prima Medika

Berdiri di areal lahan tanah seluas 1,32 Hektar dengan luas gedung-gedung utama $3853,74 \mathrm{~m}^{2}$ dan bangunan lain seluas $515,56 \mathrm{~m}^{2}$. terdiri dari 4 gedung utama yaitu gedung A, B, C dan D

Berdasarkan parameter yang dikeluarkan oleh Cecep Yudhie Rachmat: Studi Manajemen Energi di Rumah ... 
TABEL IV

LUAS LANTAI BANGUNAN UTAMA DI RS PRIMA MEDIKA

\begin{tabular}{|c|c|c|c|}
\hline No & Nama Gedung & Lantai & Luas $\left(\mathbf{m}^{2}\right)$ \\
\hline \multirow{2}{*}{1} & \multirow{2}{*}{ A } & I & 1102,5 \\
\hline & & II & 1102,5 \\
\hline \multirow{2}{*}{2} & \multirow{2}{*}{ B } & I & 550 \\
\hline & & II & 150 \\
\hline \multirow{5}{*}{3} & \multirow{5}{*}{$\mathrm{C}$} & I & 1074,24 \\
\hline & & II & 1053,7 \\
\hline & & III & 1021,25 \\
\hline & & IV & 1021,25 \\
\hline & & Top Roof & 351 \\
\hline \multirow{6}{*}{4} & \multirow{5}{*}{$\mathrm{D}$} & Basement & 541,88 \\
\hline & & I & 1127 \\
\hline & & II & 1129 \\
\hline & & III & 1129 \\
\hline & & IV & 1129 \\
\hline & \multicolumn{2}{|c|}{ Total Luas lantai Bangunan } & 12482,32 \\
\hline
\end{tabular}

Persentase komposisi luas area room dan non room adalah sebesar:

TABEL V

KOMPOSISI BANGUNAN RS. PRIMA MEDIKA

\begin{tabular}{|c|c|c|c|}
\hline No & Area & Luas $\left(\mathrm{m}^{2}\right)$ & Persentase \\
\hline 1 & Room & 3051,54 & $\mathbf{4 3 \%}$ \\
\hline 2 & Non Room & 4097,79 & $\mathbf{5 7 \%}$ \\
\hline & Total & $\mathbf{7 1 4 9 , 3 3}$ & $100 \%$ \\
\hline
\end{tabular}

\section{Persentase Komposisi Bangunan}

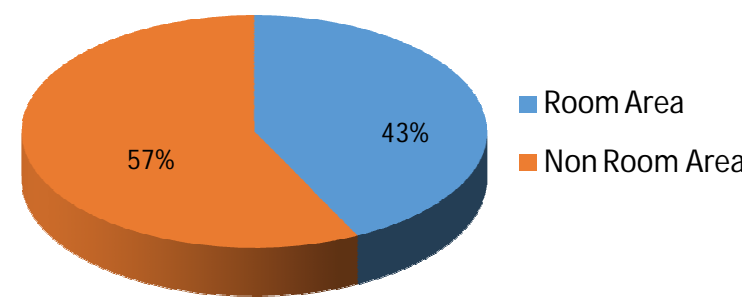

Gambar 5: Komposisi Bangunan

\section{E. Sistim Kelistrikan}

Sistim penyaluran kelistrikan yang digunakan adalah sistim Radial. Dengan 2 Sistem Radial ini dioperasikan untuk 2 area timur dan barat.

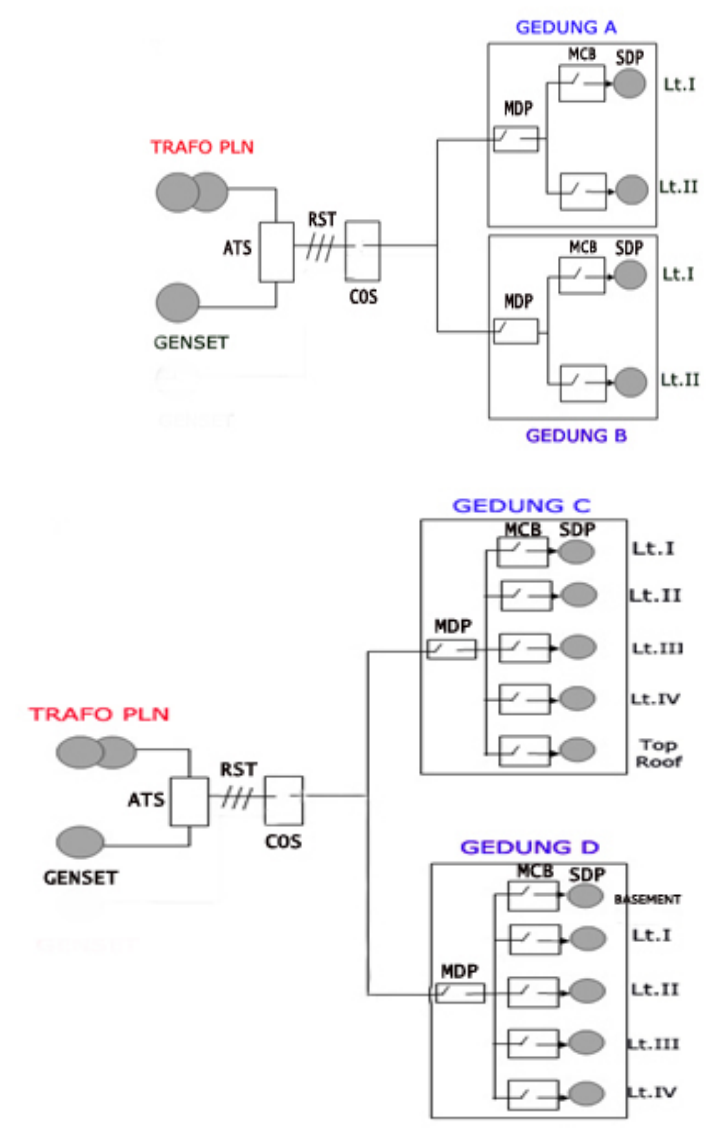

Gambar 6: Sistem kelistrikan gedung A,B dan gedung B,C

F. Audit Energi Awal

Untuk perhitungan Indeks Konsumsi Energi (IKE) Awal data yang digunakan adalah konsumsi energi listrik 2016 sebesar Rp 2.414.000.000,- yang telah dikonversikan kedalam $\mathrm{kWh}$ (setelah dibagi dengan harga listrik tahun 2016 untuk pelanggan tegangan menengah sebesar Rp 1.050,- per kWh) maka didapatkan nilai 2.299.047,62 $\mathrm{kWh} /$ Tahun persentase tingkat hunian rata rata (BOR) tahun 2016 sebesar 84,56\%. Besarnya nilai IKE yang didapat adalah:

$$
\begin{aligned}
\text { IKE }(\text { Awal }) & =\frac{k W h \text { total setahun }}{(\text { tingkat hunian } \times \text { area room })+(\text { area non room })} \\
& =\frac{2.299 .047,62}{(84,56 \% \times 3052)+(4098)} \\
& =344,23 \mathrm{kWh} / \mathrm{m}^{2} / \text { Tahun }
\end{aligned}
$$

Jika mengacu pada kreteria nilai Indeks Konsumsi Energi maka nilai IKE awal ini masuk dalam katagori Energi Intensive yaitu menunjukkan penggunaan energi yang boros.

\section{G. Inventarisasi Beban Kelistrikan}

1) Sistem Pencahayaan, terdapat 4 Jenis lampu yang digunakan yaitu jenis lampu TL, LHE, Halogen dan LED yang berjumlah total 2132 buah 
TABEL VI

KOMPOSISI BANGUNAN RS. PRIMA MEDIKA

\begin{tabular}{|c|c|c|c|c|c|c|c|c|c|}
\hline \multirow{2}{*}{ No } & \multirow{2}{*}{$\begin{array}{c}\text { Gedun } \\
\mathrm{g}\end{array}$} & \multicolumn{7}{|c|}{ Jumlah titik Lampu } & \multirow{2}{*}{$\begin{array}{l}\text { Lampu } \\
\text { Per } \\
\text { Gedung }\end{array}$} \\
\hline & & $\begin{array}{c}\text { Lantai } \\
1\end{array}$ & $\begin{array}{c}\text { Lantai } \\
2\end{array}$ & $\begin{array}{c}\text { Lantai } \\
\mathbf{3}\end{array}$ & $\begin{array}{c}\text { Lantai } \\
4\end{array}$ & $\begin{array}{l}\text { Base } \\
\text { ment }\end{array}$ & $\begin{array}{l}\text { Top } \\
\text { Roof }\end{array}$ & $\begin{array}{l}\text { Out } \\
\text { door }\end{array}$ & \\
\hline 1 & A & 167 & 192 & & & & & 40 & 399 \\
\hline 2 & B & 40 & 8 & & & & & & 48 \\
\hline 3 & $\mathrm{C}$ & 98 & 138 & 108 & 95 & & 50 & 40 & 529 \\
\hline 4 & D & 211 & 172 & 258 & 282 & 122 & 4 & 107 & 1156 \\
\hline \multicolumn{2}{|c|}{$\begin{array}{c}\Sigma \\
\text { Lampu/lantai }\end{array}$} & 516 & 510 & 366 & 377 & 122 & 54 & 187 & 2132 \\
\hline \multicolumn{2}{|c|}{ Persentase } & $24,2 \%$ & $23,9 \%$ & $17,2 \%$ & $17,7 \%$ & $5,7 \%$ & $2,5 \%$ & $8,8 \%$ & $100,0 \%$ \\
\hline
\end{tabular}

2) Sistem Penataan Udara, Unit AC yang digunakan terdiri atas beragam merek, PK, type serta jenisnya dan keseluruhannya masih memakai teknologi standart yang mulai di instoll sejak tahun 2006 dangan total keseluruhan berjumlah 252 unit.

TABEL VII

JUMLAH UNIT AC

\begin{tabular}{|c|c|c|c|c|c|c|c|c|}
\hline \multirow{2}{*}{ No } & \multirow{2}{*}{ Gedung } & \multicolumn{6}{|c|}{ Jumlah Unit AC } & \multirow{2}{*}{\begin{tabular}{|c|} 
Jumlah \\
AC \\
Per \\
Gedung \\
\end{tabular}} \\
\hline & & Lantai 1 & Lantai 2 & Lantai 3 & Lantai 4 & $\begin{array}{c}\text { Base } \\
\text { ment }\end{array}$ & $\begin{array}{l}\text { Top } \\
\text { Roof }\end{array}$ & \\
\hline 1 & A & 41 & 30 & - & - & - & - & 71 \\
\hline 2 & B & 17 & 4 & - & - & - & - & 21 \\
\hline 3 & $\mathrm{C}$ & 14 & 17 & 18 & 17 & 2 & 14 & 82 \\
\hline 4 & D & 15 & 22 & 8 & 20 & 11 & 2 & 78 \\
\hline \multicolumn{2}{|c|}{$\Sigma$ AC/Lantai } & 87 & 73 & 26 & 37 & 13 & 16 & 252 \\
\hline
\end{tabular}

3) Peralatan Medis, Jumlah peralatan medis yang ada sebanyak 263 unit yang terbagi dalam 6 kelompok pemakaian di ruangan yaitu: Peralatan Poliklinik, Peralatan UGD, Peralatan Intensive Care, Peralatan Bedah anastesi, Peralatan Laboratorium dan Peralatan Radiologi

TABEL VIII

PERALATAN MEDis

\begin{tabular}{|c|l|c|}
\hline No & \multicolumn{1}{|c|}{ Nama Alat } & Jumlah (Unit) \\
\hline 1 & Perl. Poliklinik & 21 \\
\hline 2 & Perl. UGD & 77 \\
\hline 3 & Perl. Intensive Care & 93 \\
\hline 4 & Perl. Kamar Bedah & 52 \\
\hline 5 & Perl. Laboratorium & 9 \\
\hline 6 & Perl. Radiologi & 11 \\
\hline \multicolumn{2}{|c|}{ Jumlah Alat Medis } & $\mathbf{2 6 3}$ \\
\hline
\end{tabular}

4) Peralatan Kantor, Jumlah keseluruhannya peralatan kantor adalah 206 unit

Cecep Yudhie Rachmat: Studi Manajemen Energi di Rumah ...
TABEL IX

INVENTARIS PERALATAN KANTOR

\begin{tabular}{|c|l|c|}
\hline No & \multicolumn{1}{|c|}{ Nama Alat } & Jumlah \\
\hline 1 & Kulkas & 78 \\
\hline 2 & Dispenser & 14 \\
\hline 3 & Komputer set & 25 \\
\hline 4 & Audio Set & 3 \\
\hline 5 & Kipas angin & 27 \\
\hline 5 & TV Total & $\mathbf{2 0 6}$ \\
\hline & \multicolumn{2}{|c}{} \\
\hline
\end{tabular}

5) Peralatan Utiliti, jumlah keseluruhannya adalah sebanyak 83 unit.

TABEL $X$

PERALATAN UTILITI

\begin{tabular}{|c|l|c|}
\hline No & \multicolumn{1}{|c|}{ Nama Alat } & Jumlah \\
\hline 1 & Pompa Air Tanah & 2 \\
\hline 2 & Pompa Booster & 4 \\
\hline 3 & Medical Central Compressor & 2 \\
\hline 4 & Medical Central Suction & 2 \\
\hline 5 & Water Hater & 68 \\
\hline 6 & lift & 5 \\
\hline & Total & $\mathbf{8 3}$ \\
\hline
\end{tabular}

H. Perbandingan Jumlah Peralatan berdasarkan Kelompok Inventarisasi semua peralatan berdasarkan pengelompokan alat yang ada dapat dituangkan dalam tabel berikut ini:

TABEL XI

INVENTARISASI JUMLAH PERALATAN

\begin{tabular}{|c|c|c|c|}
\hline No & Kelompok Peralatan & Jumlah (Unit) & Persentase \\
\hline 1 & Sistem Pencahayaan & 2132 & $73 \%$ \\
\hline 2 & Sistem Penataan Udara & 252 & $9 \%$ \\
\hline 3 & Medis & 263 & $9 \%$ \\
\hline 4 & Kantor & 206 & $7 \%$ \\
\hline 5 & Utiliti & 83 & $3 \%$ \\
\hline & $\Sigma$ Jumlah & 2936 & $100 \%$ \\
\hline
\end{tabular}

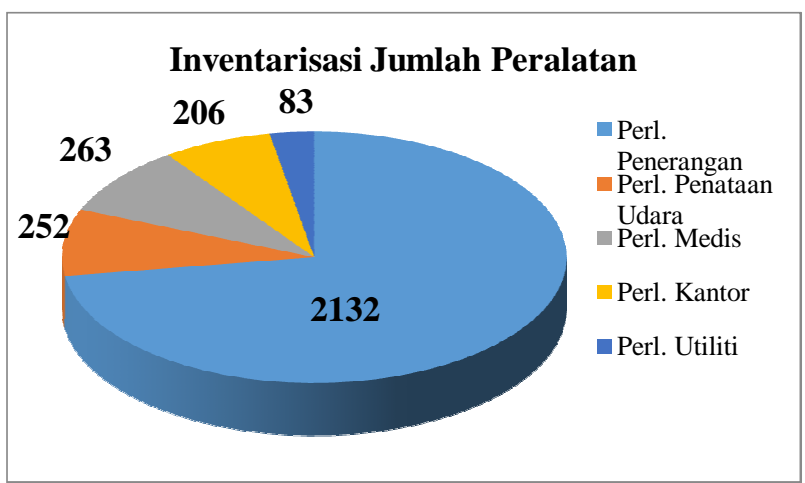

Gambar 7: Inventarisasi Jumlah Peralatan p-ISSN:1693 - 2951; e-ISSN: 2503-2372 


\section{Konsumsi Energi Listrik di RS Prima Medika}

1) Konsumsi Energi Peralatan Sistem Pencahayaan, Perhitungan konsumsi energi listrik untuk sistem pencahayaan didapat dari hasil mengalikan daya pada masing masing jenis lampu serta perkiraan berapa lama titik lampu tersebut di nyalakan.

TABEL XII

PENGELOMPOKAN POLA OPRASIONAL JAM MENYALA LAMPU PENERANGAN

\begin{tabular}{|c|l|l|c|}
\hline No & Kelompok Ruangan & \multicolumn{1}{|c|}{ Nama ruangan } & $\begin{array}{c}\text { Rara-rata nyala } \\
\text { (Jam/hari) }\end{array}$ \\
\hline 1 & PERKANTORAN & $\begin{array}{l}\text { Admin, keuangan, R.Direksi, } \\
\text { CM, Kepegawaian, R. Rapat, } \\
\text { Marketing, R teknisi, Kasir, } \\
\text { Pengadaan, IT, Dapur, } \\
\text { Chemical, gudangDiklat }\end{array}$ & 8 \\
\hline 2 & POLIKLINIK & $\begin{array}{l}\text { Fisioterapi, Gigi/mulut, } \\
\text { THT, Kebidanan, Bayi } \\
\text { tabung, Mata, Echo, jantung, } \\
\text { VK Ponek }\end{array}$ & 8 \\
\hline 3 & R.RAWAT INAP & $\begin{array}{l}\text { Presiden Suite, Executive, } \\
\text { VIP, Superior, Deluxe, } \\
\text { Junior, Kelas }\end{array}$ & 15 \\
\hline 4 & $\begin{array}{l}\text { R. INAP } \\
\text { INTENSIVE }\end{array}$ & $\begin{array}{l}\text { Intermedite, NICU, PICU, } \\
\text { ICU, Isolasi }\end{array}$ & 24 \\
\hline 5 & $\begin{array}{l}\text { R. PENUNJANG } \\
\text { MEDIK }\end{array}$ & $\begin{array}{l}\text { Laboratorium, Radiologi, } \\
\text { Apotik, Chemo, Farmasi }\end{array}$ & 24 \\
\hline 6 & KAMAR BEDAH & $\begin{array}{l}\text { OK, UGD, R. Jaga } \\
\text { UGD/OK }\end{array}$ & 24 \\
\hline 7 & $\begin{array}{l}\text { R. BASEMENT } \\
\text { DAN LANTAI I }\end{array}$ & $\begin{array}{l}\text { Seluruh ruangan yang ada pada } \\
\text { Basement dan Lantai 1 }\end{array}$ & 24 \\
\hline
\end{tabular}

Besarnya konsumsi Daya dan energi listrik yang digunakan untuk penerangan

TABEL XIII

REKAPITULASI KONSUMSI DAYA LISTRIK UNTUK PENCAHAYAAN

\begin{tabular}{|c|c|c|c|c|c|c|c|c|c|}
\hline \multirow{2}{*}{ No } & \multirow{2}{*}{$\begin{array}{c}\text { Gedun } \\
\mathrm{g}\end{array}$} & \multicolumn{7}{|c|}{$\begin{array}{c}\text { Konsumsi Daya Listrik Peralatan Sistem } \\
\text { Pencahayaan }(\mathbf{k W})\end{array}$} & \multirow{2}{*}{ 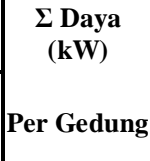 } \\
\hline & & $\begin{array}{c}\text { Lantai } \\
1\end{array}$ & $\begin{array}{c}\text { Lantai } \\
2\end{array}$ & $\begin{array}{c}\text { Lantai } \\
3\end{array}$ & $\begin{array}{c}\text { Lantai } \\
4\end{array}$ & $\begin{array}{l}\text { Base } \\
\text { ment }\end{array}$ & $\begin{array}{l}\text { Top } \\
\text { Roof }\end{array}$ & $\begin{array}{c}\text { Out } \\
\text { door }\end{array}$ & \\
\hline 1 & A & 6,07 & 4,24 & & & & & 1,48 & 11,80 \\
\hline 2 & B & 0,88 & 0,30 & & & & & & 1,18 \\
\hline 3 & $\mathrm{C}$ & 2,43 & 3,21 & 2,09 & 1,76 & & 1,27 & 1,05 & 11,81 \\
\hline 4 & D & 4,06 & 2,97 & 4,21 & 3,81 & 2,67 & 0,14 & 1,81 & 19,67 \\
\hline \multicolumn{2}{|c|}{ Jumlah } & 13,438 & 10,72 & 6,298 & 5,574 & 2,67 & 1,416 & 4,336 & 44,45 \\
\hline \multicolumn{2}{|c|}{ Persentase } & $30,2 \%$ & $24,1 \%$ & $14,2 \%$ & $12,5 \%$ & $6,0 \%$ & $3,2 \%$ & $9,8 \%$ & $100,0 \%$ \\
\hline
\end{tabular}

TABEL XIV

REKAPITULASI KONSUMSI ENERGI LISTRIK UNTUK PENCAHAYAAN

\begin{tabular}{|c|c|c|c|c|c|c|c|c|c|}
\hline \multirow{2}{*}{ No } & \multirow{2}{*}{ Gedung } & \multicolumn{7}{|c|}{ Konsumsi Energi Listrik Peralatan Sistem } & $\begin{array}{c}\text { E Energi } \\
\text { kWh/hari } \\
\text { Per } \\
\text { Pencahayaan (kWh/Hari) } \\
\text { Gedung }\end{array}$ \\
\hline 1 & A & 145,73 & 63,66 & & & & & 17,76 & 227,15 \\
\hline 2 & B & 7,04 & 2,42 & & & & & & 9,46 \\
\hline 3 & C & 58,32 & 48,09 & 16,72 & 14,10 & & 15,26 & 12,58 & 165,07 \\
\hline
\end{tabular}

\begin{tabular}{|c|c|c|c|c|c|c|c|c|c|}
\hline 4 & D & 97,34 & 23,74 & 33,66 & 739,49 & 58,74 & 1,73 & 21,70 & 976,40 \\
\hline \multicolumn{2}{|c|}{ Jumlah } & 308,43 & 137,91 & 50,38 & 753,58 & 58,74 & 16,99 & 52,03 & 1378,07 \\
\hline \multicolumn{2}{|c|}{ Persentase } & $22,4 \%$ & $10,0 \%$ & $3,7 \%$ & $54,7 \%$ & $4,3 \%$ & $1,2 \%$ & $3,8 \%$ & $100,0 \%$ \\
\hline
\end{tabular}

TABEL XV

JENIS JENIS LAMPU YANG DIGUNAKAN

\begin{tabular}{|c|c|c|c|c|}
\hline No & Jenis & Lampu & Jumlah & Persentase \\
\hline \multirow{5}{*}{1} & \multirow{5}{*}{ TL } & TL $1 \times 18$ & 68 & $3,2 \%$ \\
\hline & & TL $2 \times 18$ & 326 & $15,3 \%$ \\
\hline & & TL $1 \times 36$ & 24 & $1,1 \%$ \\
\hline & & TL $2 \times 36$ & 61 & $2,9 \%$ \\
\hline & & TL Bulat & 23 & $1,1 \%$ \\
\hline \multirow{2}{*}{2} & \multirow{2}{*}{ LHE } & Downlight & 1299 & $60,9 \%$ \\
\hline & & Spotlight & 24 & $1,1 \%$ \\
\hline \multirow{2}{*}{3} & \multirow{2}{*}{ Halogen } & Halogen & 12 & $0,6 \%$ \\
\hline & & Lampu Baret & 5 & $0,2 \%$ \\
\hline \multirow[t]{2}{*}{4} & LED & LED & 290 & $13,6 \%$ \\
\hline & \multicolumn{2}{|c|}{ Jumlah } & 2132 & $100,0 \%$ \\
\hline
\end{tabular}

Tingkat kebutuhan daya listrik sebesar 44,45 $\mathbf{k W}$ dan konsumsi energinya adalah sebesar 1378,07 kWh/hari dengan jumlah keseluruhan lampu terpasang adalah sebanyak 2132 buah

2) Konsumsi Energi Sistem Penataan Udara, Perhitungan konsumsi energi listrik untuk sistem penataan udara didapat dari daya pada masing masing AC serta perkiraan lamanya AC tersebut di nyalakan. Serta dengan memperhitungkan juga tingkat Everage Lenght of Stay (ALOS) dan tingkat Turn Over Interval (TOI) dari Rumah Sakit Prima Medika .

TABEL XVI

PENGELOMPOKAN JAM OPRASIONAL AC BERDASARKAN FUNGSI RUANGAN

\begin{tabular}{|c|c|c|c|}
\hline No & KELOMPOK & NAMA RUANGAN & $\begin{array}{c}\text { Rara-rata } \\
\text { Nyala } \\
\text { (Jam/Hari) }\end{array}$ \\
\hline 1 & PERKANTORAN & $\begin{array}{l}\text { Admin, keuangan, R.Direksi, catatan } \\
\text { medik, Kepegawaian } \\
\text { R. Rapat, Marketing, R teknisi, Kasir, } \\
\text { Orchid } \\
\text { Pengadaan, IT, Diklat, komite } \\
\text { keperawatan } \\
\text { Dapur, R Chemical, gudang, Seruni }\end{array}$ & 8 \\
\hline 2 & POLIKLINIK & $\begin{array}{l}\text { Fisioterapi, Gigi/mulut, THT, lorong } \\
\text { bedah } \\
\text { Kebidanan, Bayi tabung, Mata,SPA } \\
\text { Echo, jantung, VK Ponek, klinik gigi }\end{array}$ & 8 \\
\hline 3 & R.RAWAT INAP & $\begin{array}{l}\text { Presiden Suite, Executive, VIP } \\
\text { Superior, Deluxe, Junior, Kelas }\end{array}$ & 8 \\
\hline 4 & $\begin{array}{c}\text { R. INAP } \\
\text { INTENSIVE }\end{array}$ & Intermedit, NICU, PICU, ICU, Isolasi & 15 \\
\hline 5 & $\begin{array}{l}\text { R. PENUNJANG } \\
\text { MEDIK }\end{array}$ & $\begin{array}{l}\text { Laboratorium, Radiologi, Apotik, steril } \\
\text { OK } \\
\text { Chemo, Farmasi, HD, MOD, campur } \\
\text { obat, } \\
\text { R USG, pemulasaran, R obat }\end{array}$ & 22 \\
\hline 6 & KAMAR BEDAH & $\begin{array}{l}\text { OK, UGD, R. Jaga UGD/OK, } \\
\text { Observasi, R Bayi, VK, }\end{array}$ & 22 \\
\hline 7 & KANTOR JAGA & $\begin{array}{l}\text { Loby, Counter Perawat, Operator, Cafe, } \\
\text { Server }\end{array}$ & 12 \\
\hline 8 & R. PERTEMUAN & R Sun Flower & 3 \\
\hline
\end{tabular}


Majalah Ilmiah Teknologi Elektro, Vol. 18, No. 1, Januari - April 2019

DOI: https://doi.org/10.24843/MITE.2019.v18i01.P04

Selain itu juga didapat data daya yang dikonsumsi setiap AC berdasarkan Daya

TABEL XVII

KONSUMSI DAYA LISTRIK AC BERDASARKAN PK

\begin{tabular}{|c|c|c|}
\hline No & $\begin{array}{c}\text { Daya } \\
(\mathrm{PK})\end{array}$ & $\begin{array}{c}\text { Daya Listrik } \\
\text { (Watt) }\end{array}$ \\
\hline 1 & 0,5 & 400 \\
\hline 2 & 0,75 & 600 \\
\hline 3 & 1 & 840 \\
\hline 4 & 1,5 & 1170 \\
\hline 5 & 2 & 1920 \\
\hline 6 & 5 & 5000 \\
\hline
\end{tabular}

Dari tabel data pengelompokan jam oprasional serta data besarnya konsumsi daya dari masing masing AC didapatkan jumlah konsumsi energi listrik yang dipakai.

TABEL XVIII

KONSUMSI DAYA LISTRIK UNTUK PENATAAN UDARA

\begin{tabular}{|c|c|c|c|c|c|c|c|c|}
\hline \multirow{2}{*}{ No } & \multirow{2}{*}{ Gedung } & \multicolumn{6}{|c|}{$\begin{array}{l}\text { Konsumsi Daya Listrik Peralatan Penataan Udara } \\
\qquad(\mathbf{k W})\end{array}$} & \multirow{2}{*}{$\begin{array}{c}\Sigma \\
\text { Daya } \\
(\mathbf{k W}) \\
\text { Per } \\
\text { Gedung }\end{array}$} \\
\hline & & $\begin{array}{c}\text { Lantai } \\
1\end{array}$ & $\begin{array}{l}\text { Lantai } \\
\quad 2\end{array}$ & $\begin{array}{c}\text { Lantai } \\
3\end{array}$ & $\begin{array}{c}\text { Lantai } \\
4\end{array}$ & $\begin{array}{l}\text { Base } \\
\text { ment }\end{array}$ & $\begin{array}{l}\text { Top } \\
\text { Roof }\end{array}$ & \\
\hline 1 & A & 46,57 & 43,98 & - & - & - & - & 90,55 \\
\hline 2 & B & 19,01 & 4,68 & - & - & - & - & 23,69 \\
\hline 3 & C & 26,14 & 32,64 & 20,4 & 23,05 & 1,44 & 26,13 & 129,8 \\
\hline 4 & D & 16,68 & 24,21 & 8,7 & 25,74 & 9,12 & 3,84 & 88,29 \\
\hline \multicolumn{2}{|c|}{$\begin{array}{c}\Sigma \\
\mathrm{kW} / \text { Lantai }\end{array}$} & 108,4 & 105,51 & 29,1 & 48,79 & 10,56 & 29,97 & 332,33 \\
\hline \multicolumn{2}{|c|}{ Persentase } & $32,6 \%$ & $31,7 \%$ & $8,8 \%$ & $14,7 \%$ & $3,2 \%$ & $9,0 \%$ & $100,0 \%$ \\
\hline
\end{tabular}

TABEL XIX

KONSUMSI ENERGI LISTRIK UNTUK PENATAAN UDARA

\begin{tabular}{|c|c|c|c|c|c|c|c|c|}
\hline \multirow{2}{*}{ No } & \multirow{2}{*}{ Gedung } & \multicolumn{6}{|c|}{$\begin{array}{l}\text { Konsumsi Energi Listrik Peralatan Penataan Udara } \\
(\mathrm{kW} / \text { Hari })\end{array}$} & \multirow{2}{*}{$\begin{array}{c}\Sigma \mathrm{kWh} / \mathrm{Har} \\
\text { Per } \\
\text { Gedung }\end{array}$} \\
\hline & & $\begin{array}{c}\text { Lantai } \\
1\end{array}$ & \begin{tabular}{|c|}
$\begin{array}{c}\text { Lantai } \\
2\end{array}$ \\
\end{tabular} & $\begin{array}{c}\text { Lantai } \\
3\end{array}$ & $\begin{array}{c}\text { Lantai } \\
4\end{array}$ & $\begin{array}{c}\text { Base } \\
\text { ment }\end{array}$ & Top Roof & \\
\hline 1 & A & 790,67 & 361,92 & - & - & - & - & 1152,59 \\
\hline 2 & B & 297,66 & 102,96 & - & - & - & - & 400,62 \\
\hline 3 & $\mathrm{C}$ & 430,92 & 288 & 163,2 & 184,4 & 11,52 & 113,04 & 1191,08 \\
\hline 4 & D & 272,64 & 240,72 & 136,38 & 225,72 & 200,64 & 30,72 & 1106,82 \\
\hline \multicolumn{2}{|c|}{$\begin{array}{c}\Sigma \\
\mathrm{kW} / \mathrm{h} / \mathrm{Lantai} \\
\end{array}$} & 1791,89 & 993,6 & 299,58 & 410,12 & 212,16 & 143,76 & 3851,11 \\
\hline \multicolumn{2}{|c|}{ Persentase } & $46,5 \%$ & $25,8 \%$ & $7,8 \%$ & $10,6 \%$ & $5,5 \%$ & $3,7 \%$ & $100,0 \%$ \\
\hline
\end{tabular}

Dari data dapat diketahui jumlah keseluruhan peralatan sistem penataan udara adalah sebanyak 252 unit alat dengan kebutuhan daya sebesar $332,33 \mathbf{~ k W}$ dan konsumsi energi total sebesar 3851,11 kW/h.

3) Konsumsi Energi Peralatan Medis, perhitungan konsumsi energi listrik untuk sistem peralatan medis didapat dari daya pada masing masing peralatan medis serta perkiraan lamanya alat tersebut digunakan

TABEL XX

PENGELOMPOKAN PEMAKAIAN PERALATAN MEDIS

\begin{tabular}{|c|c|c|c|}
\hline No & Kelompok Alat & KODE & $\begin{array}{c}\text { Pemakaian } \\
\text { (jam) }\end{array}$ \\
\hline \multirow{3}{*}{1} & \multirow{3}{*}{ Perl. Poliklinik } & $1 \mathrm{~A}$ & 1 \\
\hline & & 1B & 2 \\
\hline & & $1 \mathrm{C}$ & 5 \\
\hline \multirow{3}{*}{2} & \multirow{3}{*}{ Perl. UGD } & $2 \mathrm{~A}$ & 1 \\
\hline & & $2 \mathrm{~B}$ & 2 \\
\hline & & $2 \mathrm{C}$ & 3 \\
\hline \multirow{3}{*}{3} & \multirow{3}{*}{ Perl. Intensif Care } & $3 \mathrm{~A}$ & 8 \\
\hline & & $3 \mathrm{~B}$ & 12 \\
\hline & & $3 \mathrm{C}$ & 22 \\
\hline \multirow{3}{*}{4} & \multirow{3}{*}{ Perl. OK } & $4 \mathrm{~A}$ & 2 \\
\hline & & $4 \mathrm{~B}$ & 3 \\
\hline & & $4 \mathrm{C}$ & 4 \\
\hline \multirow{3}{*}{5} & \multirow{3}{*}{ Perl. Laboratorium } & $5 \mathrm{~A}$ & 2 \\
\hline & & $5 \mathrm{~B}$ & 6 \\
\hline & & $5 \mathrm{C}$ & 22 \\
\hline \multirow{2}{*}{6} & \multirow{2}{*}{ Perl. Radiologi } & $6 \mathrm{~A}$ & 1 \\
\hline & & $6 \mathrm{~B}$ & 5 \\
\hline
\end{tabular}

Total konsumsi energi listrik yang digunakan pada kelompok peralatan medis seperti pada tabel XX

TABEL XXI

KONSUMSI ENERGI UNTUK

PERALATAN MEDIS

\begin{tabular}{|c|c|c|c|c|c|}
\hline No & NAMA ALAT & KODE & $\begin{array}{c}\text { Jumlah } \\
\text { (Unit) }\end{array}$ & $\begin{array}{l}\text { Total } \\
\text { Daya } \\
(\mathbf{k W})\end{array}$ & $\begin{array}{c}\text { Total } \\
\text { Energi } \\
(\mathbf{k W h} / \text { Hari })\end{array}$ \\
\hline \multirow{3}{*}{1} & \multirow{3}{*}{ Perl. Poliklinik } & $1 \mathrm{~A}$ & 2 & \multirow{18}{*}{104,58} & \multirow{18}{*}{612,3} \\
\hline & & $1 \mathrm{~B}$ & 17 & & \\
\hline & & $1 \mathrm{C}$ & 2 & & \\
\hline \multirow{3}{*}{2} & \multirow{3}{*}{ Perl. UGD } & $2 \mathrm{~A}$ & 4 & & \\
\hline & & $2 \mathrm{~B}$ & 11 & & \\
\hline & & $2 \mathrm{C}$ & 62 & & \\
\hline \multirow{3}{*}{3} & \multirow{3}{*}{$\begin{array}{l}\text { Perl. Intensive } \\
\text { Care }\end{array}$} & $3 \mathrm{~A}$ & 8 & & \\
\hline & & 3B & 46 & & \\
\hline & & $3 \mathrm{C}$ & 39 & & \\
\hline \multirow{3}{*}{4} & \multirow{3}{*}{ Perl. Kamar Bedah } & $4 \mathrm{~A}$ & 4 & & \\
\hline & & $4 \mathrm{~B}$ & 16 & & \\
\hline & & $4 \mathrm{C}$ & 32 & & \\
\hline \multirow{3}{*}{5} & \multirow{3}{*}{ Perl. Laboratorium } & $5 \mathrm{~A}$ & 4 & & \\
\hline & & $5 \mathrm{~B}$ & 2 & & \\
\hline & & $5 \mathrm{C}$ & 3 & & \\
\hline \multirow{2}{*}{6} & \multirow{2}{*}{ Perl Radiologi } & $6 \mathrm{~A}$ & 9 & & \\
\hline & & $6 \mathrm{~B}$ & 2 & & \\
\hline & \multicolumn{2}{|c|}{ Jumlah Alat Medis } & 263 & & \\
\hline
\end{tabular}

Dari data dapat diketahui jumlah keseluruhan alat medis adalah sebanyak 263 unit alat dengan besar kebutuhan daya total 104,58 $\mathbf{k W}$ dan konsumsi energi total sebesar $\mathbf{6 1 2 , 3}$ kWh/Hari.

4) Konsumsi Energi Peralatan Kantor, Jam oprasional peralatan kantor tersebut biasanya mengikuti sesuai jam kantor

p-ISSN:1693 - 2951; e-ISSN: 2503-2372

Cecep Yudhie Rachmat: Studi Manajemen Energi di Rumah ... 
yaitu mulai pukul 08.00 sampai pukul 16.00 wita. Kecuali untk kulkas yang dioprasionalkan selama 24 jam.

TABEL XXII

LAMA PEMAKAIAN PERALATAN PERKANTORAN

\begin{tabular}{|c|l|c|}
\hline NO & Nama Alat & $\begin{array}{c}\text { lama Pemakaian } \\
\text { (Jam/hari) }\end{array}$ \\
\hline 1 & Kulkas & 24 \\
\hline 2 & Dispenser & 8 \\
\hline 3 & Komputer set & 8 \\
\hline 4 & Audio Set & 8 \\
\hline 5 & Kipas angin & 8 \\
\hline 6 & TV & 8 \\
\hline
\end{tabular}

Berikut ini ditampilkan tabel konsumsi energi listrik untuk peralatan kantor

TABEL XXIII

KONSUMSI ENERGI UNTUK PERALATAN KANTOR

\begin{tabular}{|c|l|c|c|c|c|c|}
\hline NO & Nama Alat & $\begin{array}{c}\text { Jumlah } \\
(\text { Unit })\end{array}$ & $\begin{array}{c}\text { Daya } \\
(\text { Watt })\end{array}$ & $\begin{array}{c}\text { Total } \\
\text { Daya } \\
(\mathbf{k W})\end{array}$ & $\begin{array}{c}\text { Kerja } \\
(\text { Jam/Hari })\end{array}$ & $\begin{array}{c}\boldsymbol{\Sigma} \text { Energi } \\
(\mathbf{k W h} / \mathbf{h a r i})\end{array}$ \\
\hline 1 & Kulkas & 78 & 75 & 5,85 & 24 & 140,4 \\
\hline 2 & Dispenser & 14 & 300 & 4,2 & 8 & 33,6 \\
\hline 3 & Komputer set & 25 & 600 & 15 & 8 & 120 \\
\hline 4 & Audio Set & 3 & 500 & 1,5 & 8 & 12 \\
\hline 5 & Kipas angin & 27 & 50 & 1,35 & 8 & 10,8 \\
\hline 6 & TV & 59 & 100 & 5,9 & 8 & 47,2 \\
\hline & $\Sigma$ alat Kantor & $\mathbf{2 0 6}$ & $\Sigma$ Daya & $\mathbf{3 3 , 8}$ & $\Sigma$ Energi & $\mathbf{3 6 4}$ \\
\hline
\end{tabular}

Dari data dapat diketahui jumlah keseluruhan peralatan kantor adalah sebanyak 206 unit alat dengan besarnya kebutuhan daya $33,8 \mathbf{~ k W}$ dan konsumsi energi sebesar 364 kWh/hari

5) Konsumsi Energi Peralatan Utiliti, Perhitungan konsumsi energi listrik untuk sistem peralatan utiliti didapat dari daya pada masing masing peralatan serta perkiraan lamanya alat tersebut digunakan.

TABEL XXIV

LAMA PEMAKAIAN PERALATAN UTILITI

\begin{tabular}{|c|l|c|}
\hline NO & \multicolumn{1}{|c|}{ Nama Alat } & $\begin{array}{c}\text { lama pemakaian } \\
(\mathbf{J a m} / \text { Hari })\end{array}$ \\
\hline 1 & Pompa Air Tanah & 12 \\
\hline 2 & Pompa Booster & 12 \\
\hline 3 & Medical Central Compressor & 12 \\
\hline 4 & Medical Central Suction Central & 12 \\
\hline 5 & Water Hater & 3 \\
\hline 6 & lift & 8 \\
\hline
\end{tabular}

TABEL XXV

KONSUMSI ENERGI LISTRIK PERALATAN UTILITI

\begin{tabular}{|c|c|c|c|c|c|c|}
\hline NO & NAMA ALAT & $\begin{array}{c}\text { Jumlah } \\
\text { (Unit) }\end{array}$ & $\begin{array}{c}\text { Daya } \\
\text { (Watt) }\end{array}$ & $\begin{array}{c}\text { Total } \\
\text { Daya } \\
\text { (kW) }\end{array}$ & $\begin{array}{c}\text { Kerja } \\
(\text { Jam/Hari) }\end{array}$ & $\begin{array}{c}\text { Energi } \\
(\mathbf{k W h} / \text { hari) }\end{array}$ \\
\hline 1 & Pompa Air Tanah & 2 & 2200 & 4,4 & 12 & 52,8 \\
\hline
\end{tabular}

\begin{tabular}{|c|l|c|c|c|c|c|}
2 & Pompa Booster & 4 & 2200 & 8,8 & 12 & 105,6 \\
\hline 3 & Medical Compres & 2 & 1500 & 3 & 12 & 36 \\
\hline 4 & $\begin{array}{l}\text { Medical Suction } \\
\text { Central }\end{array}$ & 2 & 1500 & 3 & 12 & 36 \\
\hline 5 & Water Hater & 68 & 1500 & 102 & 3 & 306 \\
\hline 6 & ift & 5 & 3000 & 15 & 8 & 120 \\
\hline & $\Sigma$ peralatan Utiliti & $\mathbf{8 3}$ & $\Sigma$ Daya & $\mathbf{1 3 6 , 2}$ & $\Sigma$ Energi & $\mathbf{6 5 6 , 4}$ \\
\hline
\end{tabular}

Dari data dapat diketahui jumlah keseluruhan peralatan utiliti adalah sebanyak 83 unit alat dengan besarnya daya total $\mathbf{1 3 6 , 2} \mathbf{~ k W}$ dan konsumsi energi listrik total sebesar $\mathbf{6 5 6 , 4}$ $\mathrm{kW/h}$.

J. Rekapitulasi Konsumsi Energi Listrik

Adapun hasil rekapitulasi konsumsi energi kelistrikan secara keseluruhan adalah sebagai berikut:

TABEL XXVI

REKAPITULASI KONSUMSI ENERGI LISTRIK KESELURUHAN

\begin{tabular}{|c|l|c|c|c|c|}
\hline No & \multicolumn{1}{|c|}{$\begin{array}{c}\text { Kelompok } \\
\text { Alat }\end{array}$} & $\begin{array}{c}\Sigma \text { Daya } \\
(\mathrm{kW})\end{array}$ & $\begin{array}{c}\Sigma \text { Energi } \\
(\mathrm{kWh} / \text { Hari })\end{array}$ & $\begin{array}{c}\Sigma \text { Energi } \\
(\mathrm{kWh} / \text { Tahun })\end{array}$ & $\begin{array}{c}\text { Persentase } \\
(\%)\end{array}$ \\
\hline 1 & $\begin{array}{l}\text { Sistem } \\
\text { Pencahayaan }\end{array}$ & 44,45 & $1.378,07$ & $502.995,55$ & $\mathbf{2 0 , 0 8 \%}$ \\
\hline 2 & $\begin{array}{l}\text { Penataan } \\
\text { Udara }\end{array}$ & 332,33 & $3.851,11$ & $1.405 .655,15$ & $\mathbf{5 6 , 1 2 \%}$ \\
\hline 3 & $\begin{array}{l}\text { Peralatan } \\
\text { Medis }\end{array}$ & 104,58 & 612,30 & $223.489,50$ & $\mathbf{8 , 9 2 \%}$ \\
\hline 4 & $\begin{array}{l}\text { Peralatan } \\
\text { Kantor }\end{array}$ & 33,8 & 364 & 132.860 & $\mathbf{5 , 3 0 \%}$ \\
\hline 5 & Utiliti & 136,2 & 656,40 & $239.586,00$ & $\mathbf{9 , 5 7 \%}$ \\
\hline & $\begin{array}{c}\text { Total } \\
\text { Konsumsi }\end{array}$ & $\mathbf{6 5 1 , 3 6}$ & $\mathbf{6 . 8 6 1 , 8 8}$ & $\mathbf{2 . 5 0 4 . 5 8 6 , 2 0}$ & $100,00 \%$ \\
\hline
\end{tabular}

Dari tabel XXV dapat diketahui kebutuhan penyediaan daya listrik terbesar berasal dari kelompok peralatan penataan udara sebesar 332,33 kW/Hari diikuti oleh Kelompok peralatan utiliti sebesar 136,2 $\mathrm{kW} /$ Hari, selanjutnya dari kelompok peralatan medis sebesar 104,58 kW/Hari, kelompok peralatan sistem penerangan sebesar 44,45 kW/Hari dan terakhir dari kelompok peralatan kantor sebesar 33,8 kW/Hari. Untuk konsumsi energi listrik (kWh/Tahun) terbesar adalah berasal dari kelompok peralatan penataan udara (AC) yaitu sebesar $56,12 \%$ diikuti oleh kelompok peralatan penerangan sebesar 20,08\%, kelompok peralatan Utiliti sebesar 9,57\%, kelompok peralatan medis sebesar $8,92 \%$ dan konsumsi terkecil adalah pada kelompok peralatan kantor sebesar $5,30 \%$.

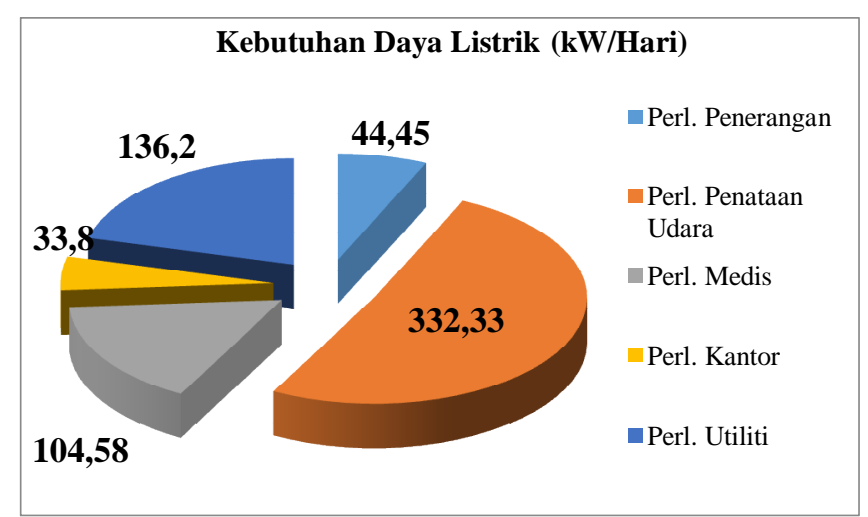

Gambar 8: Kebutuhan Daya Listrik harian 


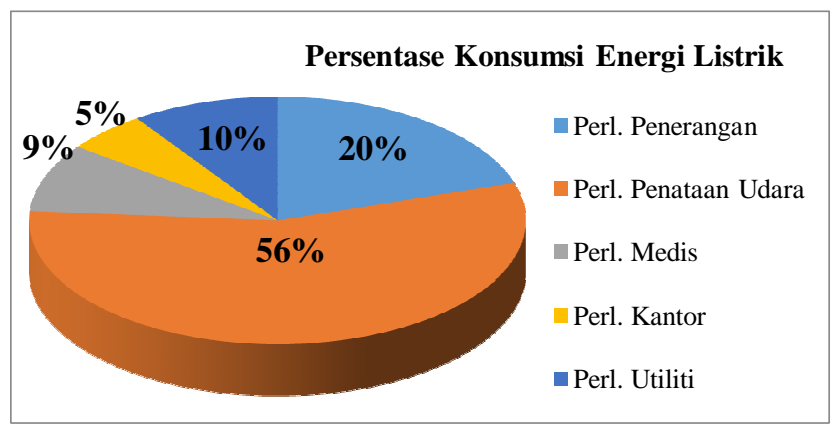

Gambar 9: Persentase Konsumsi energi listrik

\section{K. Pencarian Peluang-Peluang Penghematan Energi}

1) Kelompok Peralatan Sistem Pencahayaan, Dari jumlah titik lampu yang ada sebanyak 2132 buah dan jenis lampu yang digunakan adalah $85,7 \%$ lampu terdiri dari lampu Neon TL, Lampu Hemat Energi (LHE) dan Halogen sedangkan sisanya yang 14,3\% menggunakan jenis LED (Light Emitting Diode) dengan konsumsi energi sebesar $1378,07 \mathrm{kWh} /$ Hari atau 20,08\% dari penyerapan energi total secara keseluruhan. Jika dilakukan upaya penggantian pada jenis jenis lampu yang terhitung boros energi dan mengantikannya dengan lampu hemat energi seperti dengan menggunakan Lampu LED maka ada peluang penghematan energi yang bisa didapatkan. Dari data pada tabel XXVI terdapat perbandingannya serta potensi keuntungan yang bisa didapat jika mengganti lampu pijar atau CFL dengan lampu

TABEL XXVII

PERBANDINGAN PENGGUNAAN JENIS LAMPU PENERANGAN

\begin{tabular}{|c|c|c|c|c|}
\hline NO & KETERANGAN & Lampu Pijar & Lampu CFL & Lampu LED \\
\hline 1 & Umur Pakai & $4.000 \mathrm{jam}$ & $8.000 \mathrm{jam}$ & $40.000 \mathrm{jam}$ \\
\hline 2 & Konsumsi Listrik untuk Lumen $=5001 \mathrm{~m}$ & $50 \mathrm{~W}$ & $13 \mathrm{~W}$ & $6 \mathrm{~W}$ \\
\hline 3 & Harga Lampu & Rp. 8.000; & Rp. 20.000, & Rp. 60.000; \\
\hline 4 & $\begin{array}{l}\begin{array}{l}\text { Penggunaan Kwh listrik selama } 40.000 \\
\text { jam }\end{array} \\
\end{array}$ & $2.000 \mathrm{Kwh}$ & $520 \mathrm{Kwh}$ & $240 \mathrm{Kwh}$ \\
\hline 5 & $\begin{array}{l}\text { Tarif Listrik (Asumsi daya 1300 VA } \\
\text { @1352/ Kwh) ( no.4 × 1352/ Kwh) }\end{array}$ & Rp. 2.704.000,- & Rp. 703.040,- & Rp. 324.480 , \\
\hline 6 & Penggantian Lampu Selama 40.000 jam & $10 x$ & $5 \mathrm{x}$ & $1 \mathrm{x}$ \\
\hline 7 & $\begin{array}{l}\text { Biaya penggantian lampu baru selama } \\
40.000 \text { jam ( no.6 } 6 \text { no.3) }\end{array}$ & Rp. 80.000,- & Rp. 100.000,- & Rp. 60.000. \\
\hline 8 & $\begin{array}{l}\text { Total biaya selama } 40.000 \text { jam } \\
\text { (no. } 5+\text { no. } 7 \text { ) }\end{array}$ & Rp. 2.784.000 & Rp. 803.040 & Rp. 384.480 \\
\hline
\end{tabular}

( id.geoprivacyhelper.com

dilihat perbandingan total biaya yang harus dikeluarkan jika digunakan ketiga jenis lampu diatas. maka potensi penghematan biaya untuk energi listrik yang dapat dicapai adalah sebesar:

Potensi penghematan biaya (\%):

$$
\begin{aligned}
& =\frac{\operatorname{Rp~} 803.040-\operatorname{Rp} 384.480}{\operatorname{Rp} 803.040} \times 100 \% \\
& =\frac{\operatorname{Rp} 418.560}{\operatorname{Rp} 803.040} \times 100 \% \\
& =\mathbf{5 1 \%}
\end{aligned}
$$

Jika diasumsikan bahwa keseluruhan lampu jenis CFL/LHE, Neon TL dan halogen akan diganti dengan jenis Cecep Yudhie Rachmat: Studi Manajemen Energi di Rumah ...
LED maka analisa perhitungan potensi penghematan energi sebagai berikut:

TABEL XXVIII

POTENSI PENGHEMATAN KONSUMSI ENERGI LISTRIK DARI SISTEM PENCAHAYAAN

\begin{tabular}{|c|c|c|c|c|c|}
\hline No & Jenis & $\begin{array}{c}\text { persentase } \\
\text { jumlah } \\
\text { lampu } \\
(\%)\end{array}$ & $\begin{array}{c}\text { Konsumsi } \\
\text { Energi } \\
\text { Awal } \\
(\mathrm{kWh} / \text { hari }\end{array}$ & $\begin{array}{c}\text { Faktor } \\
\text { Penghematan } \\
(\%)\end{array}$ & $\begin{array}{c}\text { Konsumsi } \\
\text { Energi } \\
\text { akhir } \\
(\mathrm{kWh} / \mathrm{hari})\end{array}$ \\
\hline 1 & TL+LHE+Halogen & 86,4 & 1176,59 & 51 & 576,53 \\
\hline 2 & LED & 13,6 & 185,20 & Tetap & 185,20 \\
\hline & Jumlah & 100 & 1361,79 & & 761,73 \\
\hline
\end{tabular}

Potensi hemat energi (Peralatan Pencahayaan) :

$$
\begin{aligned}
& =1176,59 \mathrm{kWh} / \text { hari }-576,53 \mathrm{kWh} / \text { hari } \\
& =\mathbf{6 0 0 , 0 6} \mathbf{~} \mathbf{W h} / \mathbf{h a r i} \\
& =\mathbf{2 1 9 . 0 2 1 , 9 ~} \mathbf{k W h} / \text { Tahun }
\end{aligned}
$$

2) Kelompok Peralatan Kantor, Potensi penghematan yang dapat digalai dari kelompok peralatan kantor adalah dari penertiban jam oprasional alat Dispenser yang berdasarkan asumsi jam oprasional perharinya adalah 8 jam (sesuai jam kerja kantor dari pukul 8.00 sampai 16.00):

TABEL XXIX

ASUMSI KONSUMSI ENERGI LISTRIK ALAT DISPENSER

\begin{tabular}{|c|c|c|c|c|c|c|}
\hline NO & Nama Alat & Jumlah & $\begin{array}{c}\text { Daya } \\
\text { (Watt) }\end{array}$ & $\begin{array}{c}\text { Total Daya } \\
\text { (Watt) }\end{array}$ & $\begin{array}{c}\text { Kerja } \\
\text { (Jam/Hari) }\end{array}$ & $\mathbf{k W h / h a r i}$ \\
\hline 1 & Dispenser & 14 & 300 & 4200 & 8 & 33,6 \\
\hline
\end{tabular}

Tetapi dari hasil pengamatan dan analisa di lapangan ditemukan bahwa hampir semua Dispenser yang digunakan di ruangan dioprasionalkan terus menerus selama 24 jam walaupun kondisi kantor telah tutup. Jika dilakukan upaya penertiban dengan mengembalikan jam oprasional Dispenser sesuai jam kamtor (8 jam) akan didapatkan potensi penghematan sebesar:

Potensi hemat energi (Peralatan Kantor) :

$$
\begin{aligned}
& =33,6 \mathrm{kWh} / \text { hari } x(24-8) \mathrm{Jam} \\
& =\mathbf{5 3 7 , 6 ~} \mathbf{k W h} / \mathbf{h a r i} \\
& =\mathbf{1 9 6 . 2 2 4} \mathbf{~} \mathbf{W h} / \text { Tahun }
\end{aligned}
$$

3) Pencarian Peluang-Peluang Hematan Energi Untuk Kelompok peralatan Sistem Penataan Udara, Berdasarkan data hasil dari rekapitulasi perhitungan konsumsi energi daya listrik yang paling besar digunakan adalah pada kelompok peralatan penataan udara (AC) yaitu sebesar $56,05 \%$ dari keseluruhan konsumsi daya total yaitu sebesar 3839,59 $\mathrm{kWh} /$ hari dengan jumlah AC yang terpasang adalah sebanyak 252 unit.

4) Teknologi Peralatan Sistem Penataan Udara, Dari 252 unit AC yang dipasang hanya terdiri dari 2 tipe AC saja yaitu split dan Floor Standing dan kesemuanya masih menggunakan teknologi standar. Dari hasil penelitian Suprayogi (2014) penggantian AC dengan menggunakan

p-ISSN:1693 - 2951; e-ISSN: 2503-2372 
teknologi inverter 1,5 PK dapat diperoleh penghematan hingga $47,2 \%$ [5]

TABEL XXX

PERSENTASE AC GEDUNG A TERHADAP JUMLAH TOTAL AC

\begin{tabular}{|c|c|c|c|}
\hline No & Gedung & Jumlah AC & Konsumsi energi (kWh/Hari) \\
\hline 1 & A & 71 & 1152,59 \\
\hline 2 & Total & 252 & 3839,59 \\
\hline \multicolumn{2}{|r|}{ Persentase } & $28,17 \%$ & $30,02 \%$ \\
\hline
\end{tabular}

Jika diasumsikan bahwa seluruh AC yang ada pada gedung A yang sudah berumur lebih dari 12 tahun dengan jumlah 71 unit akan digantikan dengan yang berteknologi inverter maka akan didapat potensi penurunan konsumsi energi sebesar:

Potensi Hemat Energi AC (Teknologi)

\section{$=$ Konsumsi Daya AC Gedung A x 47,2\% \\ $=1152,59 \mathrm{kWh} /$ Hari $\mathrm{x} 47,2 \%$ \\ $=544,02 \mathrm{kWh} /$ Hari \\ $=198.567,3 \mathrm{kWh} /$ Tahun}

Sedangkan analisis selisih harga pembelian yang mungkin terjadi antara $\mathrm{AC}$ standar dan $\mathrm{AC}$ inverter dengan PK yang sama jika pembelian AC inverter yang baru dilakukan di tahun 2018, maka total investasinya adalah sebesar:

TABEL XXXI

PERBANDINGAN HARGA BELI AC STANDAR DENGAN AC INVERTER DI TAHUN 2018

\begin{tabular}{|c|c|c|c|c|c|c|}
\hline No & $\begin{array}{c}\text { Jenis } \\
\text { AC }\end{array}$ & $\begin{array}{c}\text { Daya } \\
\text { AC } \\
\text { (PK) }\end{array}$ & Harga (Rp) & $\begin{array}{l}\text { Jumlah } \\
\text { AC }\end{array}$ & $\underset{(\mathrm{Rp})}{\Sigma \text { harga tiap PK }}$ & $\begin{array}{c}\Sigma \text { Investasi } \\
(\mathrm{Rp})\end{array}$ \\
\hline \multirow{6}{*}{1} & \multirow{6}{*}{ Standar } & 0,5 & 2.410 .000 & 5 & 12.050 .000 & \multirow{6}{*}{281.300 .000} \\
\hline & & 0,75 & 2.550 .000 & 10 & 25.500 .000 & \\
\hline & & 1 & 2.850 .000 & 10 & 28.500 .000 & \\
\hline & & 1,5 & 3.450 .000 & 23 & 79.350 .000 & \\
\hline & & 2 & 5.200 .000 & 22 & 114.400 .000 & \\
\hline & & 5 & 21.500 .000 & 1 & 21.500 .000 & \\
\hline \multirow{6}{*}{2} & \multirow{6}{*}{ Inverter } & 0,5 & 3.850 .000 & 5 & 19.250 .000 & \multirow{6}{*}{444.300 .000} \\
\hline & & 0,75 & 4.010 .000 & 10 & 40.100 .000 & \\
\hline & & 1 & 4.230 .000 & 10 & 42.300 .000 & \\
\hline & & 1,5 & 5.250 .000 & 23 & 120.750 .000 & \\
\hline & & 2 & 8.400 .000 & 22 & 184.800 .000 & \\
\hline & & 5 & 37.100 .000 & 1 & 37.100 .000 & \\
\hline
\end{tabular}

Terdapat selisih harga yang cukup besar jika dilakukan pembelian AC inverter, tetapi hal tersebut hanya berlangsung pada awal pembelian saja. Adapun selisih harga yang ada adalah sebesar:
TABEL XXXII

SELISIH HARGA BELI AC STANDAR DAN AC INVERTER

\begin{tabular}{|c|c|c|c|}
\hline $\begin{array}{c}\Sigma \text { Investasi AC } \\
\text { Standar (Rp) }\end{array}$ & $\begin{array}{c}\Sigma \text { Investasi AC } \\
\text { Inverter (Rp) }\end{array}$ & Selisih (Rp) & $\begin{array}{c}\text { Persentase } \\
\text { Tingkat } \\
\text { kemahalan (\%) }\end{array}$ \\
\hline 281.300 .000 & 444.300 .000 & 163.000 .000 & $36,7 \%$ \\
\hline
\end{tabular}

Besarnya selisih investasi yang terjadi disaat pembelian AC inverter yang rata rata sebesar $36,7 \%$ tersebut, bila dibandingan dengan keuntungan yang dapat diperoleh dari besarnya efisiensi penggunaan AC inverter maka untuk mengetahui berapa lama perkiraan modal yang sudah dikeluarkan untuk pembelian AC inverter tersebut akan kembali (Break even point) dapat dilihat pada tabel XXXII (tarif dasar listrik yang dipakai untuk perhitungan adalah tarif untuk pelanggan tegangan menengah tahun 2018 sebesar Rp 1.114,74,-/kWh), yaitu:

TABEL XXXIII

PENGEMBALIAN MODAL (BREAK EVEN POINT) INVESTASI

\begin{tabular}{|c|c|c|c|c|c|c|}
\hline No & Item & $\begin{array}{c}\text { Efisiensi } \\
\text { Energi listrik } \\
(\text { Kwh/Hari) }\end{array}$ & $\begin{array}{c}\text { Efisiensi } \\
\text { Energi listrik } \\
(\text { Kwh/Tahun })\end{array}$ & $\begin{array}{c}\text { Harga } \\
\text { listrik per } \\
\text { kwh } \\
(\text { Rp) }\end{array}$ & $\begin{array}{c}\Sigma \\
\text { Keuntungan } \\
\text { per tahun } \\
(\mathrm{Rp})\end{array}$ & $\begin{array}{c}\text { Break } \\
\text { Even } \\
\text { Point } \\
\text { Tahun })\end{array}$ \\
\hline 1 & $\begin{array}{c}\text { Keuntungan } \\
\text { (Efisiensi } \\
\text { Energi } \\
\text { listrik) }\end{array}$ & 544,02 & $198.567,3$ & $1.114,74$ & $\mathbf{2 2 1 . 3 5 0 . 9 1 2}$ & \\
\hline 2 & $\begin{array}{c}\text { Investasi } \\
\text { Selisih harga } \\
\text { pembelian } \\
\text { antara AC } \\
\text { Inverter dan } \\
\text { AC Standar } \\
\text { (Rp) }\end{array}$ \\
\hline
\end{tabular}

Dari data hasil analisis diatas didapatkan bahwa selisih kemahalan investasi yang telah dikeluarkan untuk mengganti teknologi peralatan sistem penataan udara dengan menggunakan AC Inverter akan balik modal (Break Even Point) setelah 0,7 tahun atau 8,4 bulan

\section{Rekapitulasi Peluang Hemat Energi Kelompok Peralatan}

Dari kelima kelompok peralatan dapat direkapitulasi potensi potensi penghematan yang bisa diperoleh yaitu:

TABEL XXXIV

RAKAPITULASI PELUANG HEMAT ENERGI (PHE) DARI KELOMPOK ALAT

\begin{tabular}{|c|c|c|c|c|c|}
\hline No & $\begin{array}{c}\text { Kelompok } \\
\text { Peralatan }\end{array}$ & $\begin{array}{c}\text { Peluang Hemat } \\
\text { Energi }\end{array}$ & $\begin{array}{c}\text { PHE } \\
(\mathrm{kWh} / \text { Hari })\end{array}$ & $\begin{array}{c}\text { PHE } \\
\text { (kWh/tahun) }\end{array}$ & $\begin{array}{c}\sum \text { PHE } \\
(\mathrm{kWh} / \text { Tahun })\end{array}$ \\
\hline 1 & $\begin{array}{l}\text { Peralatan } \\
\text { Sistem } \\
\text { Penerangan }\end{array}$ & $\begin{array}{l}\text { Penggantian lampu } \\
\text { Neon, LHE dan } \\
\text { Halogen dengan } \\
\text { lampu jenis LED }\end{array}$ & 600,06 & $219.021,90$ & $219.021,90$ \\
\hline \multirow{3}{*}{2} & \multirow{3}{*}{$\begin{array}{l}\text { Peralatan } \\
\text { Sistem } \\
\text { Penataan } \\
\text { Udara }\end{array}$} & $\begin{array}{l}\text { 1. Teknologi : } \\
\text { Mengganti semua } \\
\text { AC standart yang } \\
\text { ada di Gedung A } \\
\text { dengan AC } \\
\text { berteknologi Inverter }\end{array}$ & 544,02 & $198.567,30$ & \multirow{3}{*}{$198.567,30$} \\
\hline & & $\begin{array}{l}\text { 2. Instalasi : } \\
\text { Perbaiki ulang } \\
\text { pemasangan AC } \\
\text { yang tidak sesuai } \\
\text { panduan yang benar }\end{array}$ & & & \\
\hline & & $\begin{array}{l}\text { 3. Selubung } \\
\text { Bangunan : } \\
\text { Tambahan Korden }\end{array}$ & & & \\
\hline
\end{tabular}




\begin{tabular}{|c|c|c|c|c|c|}
\hline & \multicolumn{2}{|c|}{ 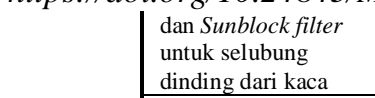 } & & & \\
\hline & & $\begin{array}{l}\text { 4. Pemeliharaan: } \\
\text { Buat program } \\
\text { pemeliharaan rutin } \\
\text { untuk AC }\end{array}$ & & & \\
\hline & & $\begin{array}{l}\text { 5. Prilaku : Perlu } \\
\text { ada petunjuk } \\
\text { pemakaian AC di } \\
\text { ruangan rawat biasa }\end{array}$ & & & \\
\hline 3 & $\begin{array}{l}\text { Peralatan } \\
\text { Medis }\end{array}$ & $\begin{array}{l}\text { Perlu ditingkatkan } \\
\text { ketrampilan operator } \\
\text { peralatan medis }\end{array}$ & & & \\
\hline 4 & $\begin{array}{l}\text { Peralatan } \\
\text { Kantor }\end{array}$ & $\begin{array}{l}\text { Pengoprasian } \\
\text { Dispenser agar } \\
\text { sesuai dengan pola } \\
\text { jam pemakaian }\end{array}$ & 537,6 & 196.224 & 196.224 \\
\hline 5 & $\begin{array}{l}\text { Peralatan } \\
\text { Utiliti }\end{array}$ & $\begin{array}{l}\text { Diperlukan petunjuk } \\
\text { penggunaan Lift } \\
\text { terutama untuk } \\
\text { pengunjung pasien } \\
\end{array}$ & & & \\
\hline & & $\Sigma$ JUMLAH PHE & 1681,68 & $613.813,20$ & $613.813,20$ \\
\hline
\end{tabular}

Dari hasil keseluruhan jumlah peluang hemat energi (PHE) yang sudah didapatkan selanjutnya dilakukan perhitungan untuk mendapatkan nilai intensitas konsumsi energi akhir.

TABEL XXXV

POTENSI EFISIENSI PEMAKAIAN ENERGI LISTRIK

\begin{tabular}{|c|c|c|c|}
\hline $\begin{array}{c}\mathrm{A} \\
\begin{array}{c}\text { Konsumsi Energi } \\
\text { Awal } \\
(\mathrm{kWh} / \text { Tahun) }\end{array}\end{array}$ & $\begin{array}{c}\mathrm{B} \\
\text { Plat (kWh/Tahun) Kelompok }\end{array}$ & $\begin{array}{c}\mathrm{C}=(\mathrm{A}-\mathrm{B}) \\
\text { Konsumsi Energi } \\
\text { Akhir (kWh/Tahun) }\end{array}$ & $\begin{array}{c}\mathrm{D}=(\mathrm{A}-\mathrm{C}) / \mathrm{A} \mathrm{x} \\
100 \%\end{array}$ \\
\hline $2.299 .047,62$ & $613.813,20$ & $1.685 .234,42$ & $26,70 \%$ \\
\hline
\end{tabular}

PHE yang didapat dari kelompok peralatan adalah sebesar $613.813,20 \mathrm{kWh} /$ tahun atau 26,70\% dari nilai energi awal, dengan nilai konsumsi energi listrik akhir sebesar 1.685.234,42 kWh/Tahun. Besarnya selisih nilai energi listrik diatas adalah merupakan potensi efisiensi konsumsi energi listrik yang bisa didapat setiap tahunnya (kWh/Tahun) jika peluang peluang hemat energi tersebut bisa di implementasikan menjadi program nyata dalam bentuk pengelolaan sistem energi yang baru. Jika dikonversikan kedalam nilai rupiah (dengan menggunakan pola tarif listrik tahun 2018, sebesar Rp 1114,74/kWh) didapat nilai:

TABEL XXXVI

POTENSI KEUNTUNGAN YANG DAPAT DIPEROLEH

\begin{tabular}{|c|c|c|c|}
\hline $\begin{array}{c}\text { Besarnya selisih } \\
\text { Energi Listrik } \\
(\mathrm{kWh} / \text { Tahun })\end{array}$ & $\begin{array}{c}\text { Tarif } \\
\text { listrik/kWh } \\
\text { tahun 2018 } \\
(\mathrm{Rp})\end{array}$ & $\begin{array}{c}\text { Potensi keuntungan } \\
\text { (Rp/Tahun) }\end{array}$ & $\begin{array}{c}\text { Potensi } \\
\text { keuntungan } \\
\text { (Rp/Hari) }\end{array}$ \\
\hline $\mathbf{6 1 3 . 8 1 3 , 2}$ & $\mathbf{1 . 1 1 4 , 7 4}$ & $\mathbf{6 8 4 . 2 4 2 . 1 2 6 , 6}$ & $\mathbf{1 . 8 7 4 . 6 3 5 , 9 6}$ \\
\hline
\end{tabular}

Potensi keuntungan yang bisa diperoleh sebesar Rp 1.874.635,96/hari atau Rp 684.242.126,6/tahun.

\section{Perhitungan IKE Akhir setelah PHE}

Nilai IKE akhir yang akan dihitung disini adalah merupakan nilai IKE yang bisa didapat jika peluang-peluang hemat energi yang sudah digali dapat diimplementasi menjadi

Cecep Yudhie Rachmat: Studi Manajemen Energi di Rumah ... program nyata dalam bentuk pengelolaan energi yang baru oleh pihak RS Prima Medika. Besarnya nilai PHE yang digunakan adalah sebesar 1.685.234,42 kWh/Tahun, sehingga didapatkan:

$$
\begin{aligned}
& \text { IKE Akhir }=\frac{k \text { Wh total setahun }}{(\text { tingkat hunian } \times \text { area room })+(\text { area non room })} \\
& =\frac{1.685 .234,42}{(84,56 \% \times 3052)+(4098)} \\
& =252,33 \mathrm{kWh} / \mathrm{m}^{2} / \text { Tahun }
\end{aligned}
$$

Jika mengacu pada tabel indeks konsumsi energi, maka nilai IKE akhir ini masuk dalam katagori Energy Standart menunjukan energi terkelola dengan baik dan sudah menerapkan hemat energi atau efisien karena nilainya berada pada $270>\mathrm{IKE}>180 \mathrm{kWh} / \mathrm{m}^{2} /$ tahun

\section{N. Perbandingan IKE Awal dan IKE Akhir}

Nilai IKE awal yang dimaksud disini adalah nilai IKE riil yang didapat berdasarkan jumlah tagihan pada rekening pembayaran listrik sedangkan IKE akhir adalah nilai IKE yang bisa diperoleh jika potensi peluang hemat energi dapat diimplementasikan dalam tindakan nyata

TABEL XXXVII

PERBANDINGAN IKE AWAL DAN AKHIR

\begin{tabular}{|c|c|c|c|}
\hline No & Item & IKE Awal & IKE Akhir \\
\hline 1 & $\begin{array}{c}\text { Nilai } \\
\left(\mathrm{kWh} / \mathrm{m}^{2} / \text { Tahun }\right)\end{array}$ & 344,23 & 252,33 \\
\hline 2 & Indeks & Energi Intensive & $\begin{array}{c}\text { Energy } \\
\text { Standart }\end{array}$ \\
\hline 3 & Katagori & Boros & Efisien \\
\hline
\end{tabular}

O. Rekomendasi Pengelolaan Energi Sistem Penataan Udara

Untuk menjaga agar tingkat efisiensi penggunaan energi listrik tetap dapat dipertahankan tanpa mengurangi kenyamanan dari pasien dan pengunjung rumah sakit maka perlu direkomendasikan hal-hal sebagai berikut:

- Agar segera dilakukan perbaikan pada sistem pengelolaan penataan udara karena dapat menghasilkan perubahan tingkat konsumsi energi listrik yang cukup signifikan

- Agar diupayakan untuk penggantian AC yang masih memakai teknologi standart dengan yang telah berteknologi inverter terutama untuk unit AC yang umurnya sudah lebih dari 5 tahun untuk perbaikan indeks IKE

- Agar dipastikan bahwa daya listrik (PK) AC sudah cukup sesuai dengan luas area $\left(\mathrm{m}^{2}\right)$ ruangan yang akan didinginkan

- Agar pastikan bahwa pada saat pemasangan AC baru, cara pemasangan, lokasi penempatan dan jarak antaranya sudah mengacu pada petunjuk pemasangan AC yang biasanya sudah disertakan dalam pembelian unit baru

- Pastikan terdapat korden atau penutup kaca (sun block) yang cukup pada ruangan yang selubung bangunannya dominan terbuat dari bahan

p-ISSN:1693 - 2951; e-ISSN: 2503-2372 
- Agar segera disusun dan dilaksanakan program pemeliharaan untuk peralatan terutama AC

- Agar disusun panduan pemakaian AC khususnya di ruangan rawat

- Agar dilakukan pengawasan rutin penggunaan AC diruangan-ruangan perawatan biasa

- Perlu dibudayakan perilaku hemat energi segala disektor yang ada dalam linkungan rumah sakit

- Peningkatan kualitas serta kuantitas teknisi internal sangat diperlukan.

\section{KESIMPULAN}

Dari hasil penelitian ini dapat diambil beberapa kesimpulan yaitu:

1. Lakukan upaya hemat energi maka potensi penghematan yang bisa didapat bisa mencapai $26,70 \%$ dan dapat menurunkan tingkat konsumsi energi (IKE) awal dari sebesar $344,23 \mathrm{kWh} / \mathrm{m}^{2} /$ Tahun dan berada dalam katagori 'Energy Intensive' yang berarti boros menjadi $252,33 \mathrm{kWh} / \mathrm{m}^{2} /$ Tahun yang berarti masuk dalam katagori 'Energy Standart' yang menunjukan tingkat konsumsi energi yang efisien.

2. Dari hasil Studi terhadap pengelolaan energi di RS Prima Medika menunjukan bahwa dari kelima kelompok peralatan penyerap energi listrik diketahu bahwa peralatan sistem penataan udara merupakan kelompok penyerap energi terbesar yaitu 56,12\% dikuti oleh peralatan sistem penerangan sebesar $20,08 \%$, peralatan utiliti $9,57 \%$, Peralatan medis $8,92 \%$ dan peralatan kantor $5,30 \%$

3. Model pengelolaan energi yang lebih efektif dan efisien di RS Prima Medika adalah dengan mengganti sebagian dari AC yang sudah berumur diatas 5 tahun dengan $\mathrm{AC}$ yang telah menggunakan teknologi inverter, menambah selubung berupa korden atau filter sun block guna mengurangi penetrasi suhu panas matahari yang dapat menyebabkan meningkatnya suhu ruangan, membuat dan melaksanakan program pemeliharaan untuk AC guna mengurangi tingkat kerusakan pada peralatan sistem penataan udara, menempatkan AC pada posisi yang sesuai dengan panduan pemasangan AC yang baik dan benar terutama pada instoll awal AC serta diperlukan keseriusan dari pihak Managemen untuk lebih memperhatikan pengelolaan energi dilingkungan RS Prima Medika

\section{REFERENSI}

[1] HN Pratama,2016, Studi Pengelolaan Energi Listrik di Perusahaan Pengolahan Daging PT. Soejasch Bali

[2] Weda setyawan, I Putu Gede, 2012, Manajemen Energi di Rumah Sakit Surya Husadha Denpasar

[3] Affan Bachri2015, Analisis Efisiensi Pemakaian Daya Listrik di Universitas Islam Lamongan

[4] Widya Artati, 2016, Studi Terhadap Manajemen Energi di Rumah Sakit Umum Pusat Sanglah Denpasar

[5] Muhammad Rigadho Suprayogi, 2014, Analisis Audit Energi pada Beban HVAC (Heat, Ventilation and Air Conditioner) Di Rumah Sakit Umum Daerah Dr. Syaiful Anwar Malang

[6] PT. Surya Prima Cipta, Company Profile RSU Prima Medika,2016
[7] Journal Report, Prima Medika Hospital, Pembayaran listrik periode 0101-2016 s/d 31-12-2016

[8] Journal Report, Prima Medika Hospital, Pembayaran listrik periode 0101-2017 s/d 31-12-2017

[9] Departemen Energi dan Sumber Daya Mineral,Peraturan Menteri Energi dan Sumber Daya Mineral Republik Indonesia No.14 tahun 2012 tentang Manajemen Energi.

[10] Direktorat Instalasi Medik, Direktorat Jenderal Pelayanan Medik, Departemen Kesehatan RI, 2010,Pedoman Pencahayaan di Rumah Sakit

[11] Direktorat Instalasi Medik, Direktorat Jenderal Pelayanan Medik, Departemen Kesehatan RI, 2012,Pedoman sistem tata udara Rumah Sakit

[12] Presiden Republik Indonesia, no: 10/2005, Instruksi Presiden tentang Penghematan Energi

[13] Instruksi Presiden no 10 tahun2005 Tentang penghematan energi

[14] Peraturan Presiden no 70 tahun 2009 tentang konservasi energi

[15] https://www.nationalelektronik.com/wp-content/uploads /2015/03/ACInverter-lebih-stabil-menjaga-temperatur -ruangan.png

[16] http://www.sempurna.net/2016/08/daftar-harga-ac-hemat-listrik2017.html 